\title{
CLASSROOM SOCIAL BEHAVIOR OF HEARING IMPAIRED CHILDREN
}

\author{
Shaista Majid* \\ Madeeha Saif**
}

\begin{abstract}
Social interaction has an impact on the development of communication skills, social adaption, long-term relationships, and the development of cognition, emotion and personality in unique and important ways. Children with hearing impairment often have some degree of language and/or speech delay, which is a major factor affecting their social interaction with peers. The present research was aimed at the study of classroom social behavior of hearing impaired children at primary level. The research was descriptive and direct observation method was used to identify the positive and negative social behavior of hearing impaired children exhibited in the classroom and at playground. 50 hearing impaired children including male and female studying in classes I to $V$ of special education centers for children with hearing impairment at Islamabad were selected randomly. A checklist was used to identify the social behavior. The items were developed on the indicators of classroom social behavior of hearing impaired children such as respect of elders, sharing, rebel, aggressive behavior, cooperation, fighting, calm and quiet, follow the instructions, teasing others, and friendly etc.

On the basis of research findings it was concluded that most of hearing impaired children respect their elders, remain calm and quite during lesson, do not share their things with other students, do not rebel during lesson. Most of them cooperate with others during group activities, stay away from fighting during group activities, and follow the rules in playing group games. Some of them get angry when other students distract them from their studies, do not tease their friends. The male children immediately become frustrated when they can't solve a problem and become aggressive (violent) when something goes against their will. It was recommended that creating awareness of classroom social behavior in hearing impaired children can change their behavior positively. Moreover, hearing impaired children should be motivated and encouraged to move in a positive social life.
\end{abstract}

Key words: classroom social behavior, hearing impaired children, positive social behavior, negative social behavior

\footnotetext{
*Assistant Professor, Department of Special Education, Allama Iqbal Open University, Islamabad. **Scholar Session 2009 at Department of Special Education, Allama Iqbal Open University, Islamabad, Pakistan.
} 


\section{Introduction}

All human beings are social in nature and need to communicate to live in the society. Social skills that are appropriate for proper social development of the children comprised of listening and conversational turn taking, expressing emotions, and building a child's self esteem and confidence. Children begin to learn social skills early in life. They are constantly watching and imitating the actions of their parents, family and friends. A hearing impaired child's ability to develop social skills depends upon his or her degree of hearing loss, age of diagnosis, treatment and the experience he had faced.

Todd and McLaughlin (2002) say that the social skills which children develop include: making friends, being a friend, turn taking, asking for help, initiating conversation, join social groups, appropriate expression of feelings, and recognizing and choosing appropriate behaviors. These skills can be taught by model, social skills exercises, and group activities.

Odom, Mc Connell, and McEvoy (1992) said that being social is a child's strength in effecting his colleague's social behavior and responsibility in a specific setting, context and/or culture. Peer interaction is quite helpful for the children to build stronger and more mature social bonding for their adult life. This successful mutual interaction assists them to build mutual trust, develop humor, control their emotional response, resolve conflicts and respond to aggression and violence in a better way. In this way the children would grow to become effective and well adjusted adults.

Qayyum \& Nadeem (2012) in their research concluded that apart from the fact that play has a major role not only in holistic development of the children with disabilities but also a strong tool for strengthening their potentials and builds their behaviors and personalities.

Common characteristic of hearing impairment comprised of the use of gestures to communicate, try to imitate or copy other people, and sometimes not follow the directions. The classroom related problems of children with hearing impairment include; learning problems, poor academic performance, and interpersonal difficulties. The study intends to point out the positive as well as negative social behavior of the students particularly in the classroom environment.

\section{Social impact of hearing impairment}

Hearing impairment is the loss of hearing in one or both ears causing hearing loss at different degrees like; mild, moderate, severe and profound deafness. Communication is the major hurdle which a person with hearing impairment faces. BatChava and Deignan (2001) noted that language delay and speech development in children create difficulties in establishing and sustaining social relationships in the classroom.

Hearing loss can result in social isolation. The child who experiences delayed social progress also experiences delayed language acquisition and become unable to understand social cues. As much the person is engaged in the society as much is he/she accepted in his social circle. Acceptance in the society is defined as an ability to 
participate; produces alter and perform appropriate and productive behavior which will result in better opportunities for the social interaction with others. Several aspects have been taken into account by researchers as indicators of successful social interaction for children having disability and have manifested that if a child displays more competent behavior there are more chances for the child for being selected by their fellows as partners in future activities. The hearing impairment children use strategies for conversation initiation in the classroom similar to normal hearing children such as including nonverbal entry, extending an invitation, offering an object, or producing a behavior similar to that in which other children were engaged (Weisel, Most \& Efron, 2005).

Weisel, Most and Efron (2005) reported that "deaf preschoolers preferred to use signing, direct entrance, heading turning in search of a partner when interacting with deaf peers, whereas with hearing peers more often utilized moving closer, objectrelated social acts (for instance, pointing or showing an object), and neutral touch". While Vandell \& George, (1981) are of the view that hearing impaired children probably start conversation with wrong signals which cannot be understand, for instance, gestures or vocalizations to one's back. "They often wait and hover, use a behavior unrelated to ongoing activity, or disrupt the ongoing play to attempt to join in peer interaction (e.g., non-play activity), leading to more failure in gaining peer play" (Brown, Remine, Prescott \& Rickards, 2000).

\section{Social Behavior of Hearing Impaired Children in Classroom}

Behavior means some peculiar attitudes and actions of hearing impaired children in classroom (Henggeler, et al, 1990). It represents a complete step by step access to changing inappropriate student behavior to appropriate behavior. The socially disapproved conducts leads to behavior problem and a person classifies them as bad behavior. Galloway and Goodwin (1987) say that many pupils with behavior problems have poor social skills.

Children who are grown up with behavior problems are maladjusted in the society and they feel insecurity and unhappiness due to their inability to cope with the environment and therefore maintain their personal relationships. Such children do not obey the discipline and classroom routines, got criticized by their teacher and peers.

In sociological hierarchy, social behavior is processed by social action of the persons. These social actions are directed at other people and bringing about consequences (Webster, online). Social behavior is a process of maintaining communication with other members of the society. While, the social problems become more troublesome with growing age of the child. Child is a part of the social system of the classroom, if he faces social strains, anxiety may be developed among peer group.

According to Antia, Reed \& Shaw, (2011) awareness plays a great role in classroom social interaction between children with hearing impairment and hearing peers. In a study Lederberg as cited in Marschark, M. (1997), observed 29 hearing impairment children who were grouped into high, medium and low language ability levels during out-door free play with peers and find out that high language ability 
children initiated significantly more interactions and spent significantly more time on playing, and also used significantly more linguistic communication with partners than those who had medium or low language ability.

\section{Positive Social Behavior}

Hearing impaired children demonstrate positive as well as negative social behavior. Sometimes they love their family members and the fellows who also do so in return. Sometimes these children prove more caring than their normal peers. They behave humbly in different situations. Children with hearing impairment need friends so that they can communicate and share their feelings. Few of them are found more punctual and anxious for their studies and other activities. They prove to be very noisy and thrilling on their birthdays and national occasions like Independence Day. Happiness leads towards the positive social behavior of the students because being close to their family members and friends give them sense of security.

\section{Negative Social Behavior}

As a result of being hated and neglected by the society most of children with hearing impairment hesitate communication, they become stressed and feel as if they are burden for everyone in their family. In such case they behave rudely with their peers, teachers, even to their parents because they experience negligence. Due to this insolence and abomination they feel themselves bashful or become aggressive in several situations.

\section{Objectives of the Study:}

The study intended to achieve the following objectives:

1. To study the classroom social behavior of children with mild, moderate and severe hearing impairment at primary level of education.

2. To identify the positive and negative social behavior of hearing impaired children exhibited in the classroom and at playground.

3. To compare the gender differences on positive and negative social behavior of children with hearing impairment in the classroom.

\section{Research questions}

Following were the research questions:

1. What is the magnitude of positive and negative social behavior of hearing impaired children?

2. Which type of social behavior the hearing impaired children exhibit in the classroom during lessons and at playground?

3. How do the hearing impaired children differ on the types of social behavior gender wise? 


\section{Methodology}

The research was descriptive in nature as it targeted to study the classroom social behavior of children with mild, moderate and severe hearing impairment at primary level. Direct observation method was used to identify the positive and negative social behavior of hearing impaired children exhibited in the classroom and at playground.

\section{Population}

Population of the research study comprised of the hearing impaired students studying at primary level in Special Education Center for Hearing Impaired Children in Islamabad.

\section{Sample}

A sample for the research was selected from the population by simple random sampling technique. Fifty (50) hearing impaired children were taken as sample of the research (25 hearing impaired students from girl's wing and 25 hearing impaired students from boy's wing).

\section{Instrument}

A check list containing 40 items was developed to observe the behavior of children with hearing impairment in the classroom after thorough study of related literature and observation based information gathered by and observing the hearing impaired students directly in their classrooms and play ground.

\section{Results}

The information on classroom social behavior of the Hearing impaired children was gathered through a check list. The data on check list was collected by the researcher from National Special Education Center for Hearing Impaired Children at primary level of education in Islamabad. The data collected through the checklist is analyzed and tabulated as below:

Table 1

\begin{tabular}{|c|c|c|c|c|c|}
\hline \multirow{3}{*}{$\begin{array}{l}\text { Item } \\
\text { No. }\end{array}$} & \multicolumn{2}{|c|}{ Positive Social Behavior } & \multicolumn{2}{|c|}{$\mathrm{N}=50$} & \multirow[b]{2}{*}{$\%$} \\
\hline & Behavior & Yes & $\%$ & No & \\
\hline & & & age & & age \\
\hline 1 & $\begin{array}{l}\text { She/ He greets teacher without } \\
\text { reminder. }\end{array}$ & 48 & 96 & 2 & 4 \\
\hline 2 & $\begin{array}{l}\text { She/ He pays attention to the } \\
\text { teacher during lesson. }\end{array}$ & 41 & 82 & 9 & 18 \\
\hline 3 & $\begin{array}{l}\text { She/ he becomes worried when } \\
\text { teacher says her/ his answer is } \\
\text { wrong. }\end{array}$ & 47 & 94 & 3 & 6 \\
\hline 4 & $\begin{array}{l}\text { She/ He makes different voices } \\
\text { during lesson and make noise. }\end{array}$ & 44 & 88 & 6 & 12 \\
\hline 5 & $\begin{array}{l}\text { She/ He maintains discipline in the } \\
\text { classroom. }\end{array}$ & 40 & 80 & 10 & 20 \\
\hline
\end{tabular}


$\begin{array}{llllll}6 & \text { She/ He gives respect to her/ his } & 36 & 72 & 14 & 28\end{array}$ elders.

$\begin{array}{llllll}7 & \text { She/ he cares for her/ his studies. } & 29 & 58 & 21 & 42\end{array}$

8 She/ He obeys teacher's $\begin{array}{lllll}32 & 64 & 18 & 36\end{array}$ instructions.

$\begin{array}{lllllll}9 & \text { She/ He remains calm and quite } & 44 & 88 & 6 & 12\end{array}$ during lesson.

$\begin{array}{llllll}12 & \text { She / He are friendly with his peers. } & 29 & 68 & 7 & 32\end{array}$

$\begin{array}{llllll}19 & \text { She /He shares her / his things with } & 16 & 46 & 21 & 54\end{array}$ others.

21 She / He participates in group $\begin{array}{llll}25 & 50 & 25 & 50\end{array}$ activities.

$\begin{array}{llllllll}23 & \text { She / He cooperates with others } & 46 & 92 & 4 & 8\end{array}$ during group activities.

$\begin{array}{llllll}25 & \text { She / He likes to be neat and tidy. } & 39 & 78 & 11 & 22\end{array}$

$\begin{array}{llllll}26 & \text { She / He are happy to play a game } & 48 & 96 & 2 & 4\end{array}$ with others.

$\begin{array}{llllll}27 & \text { She/ He plays independently. } & 47 & 94 & 3 & 6\end{array}$

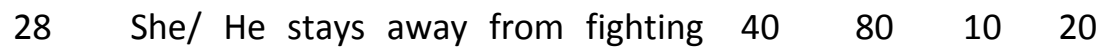
during group activity

$\begin{array}{llllll}30 & \text { She / He follows the rules in playing } & 37 & 74 & 13 & 26\end{array}$
group games.

$\begin{array}{llllll}31 & \text { She/ He cares for others during play } & 36 & 72 & 14 & 28\end{array}$ a game.

$\begin{array}{llllll}32 & \text { She/ He enjoys playing with others. } & 48 & 96 & 2 & 4\end{array}$

$\begin{array}{llllll}33 & \text { She /He feels relax after playing a } & 47 & 94 & 3 & 6\end{array}$ game.

$\begin{array}{llllll}34 & \text { She/ He eats calmly and quietly. } & 37 & 74 & 13 & 26\end{array}$

$\begin{array}{llllll}35 & \text { She/ He shares her/ his eatable with } & 26 & 52 & 24 & 48\end{array}$ others.

$\begin{array}{llllll}37 & \text { She } / \text { He takes interest in Language, } & 47 & 94 & 3 & 6\end{array}$ Oral work, Science, Written work, and Art

39 She/ He discusses her/ his thoughts $27 \quad 54 \quad 23 \quad 46 \%$ with the teacher in the classroom.

40 She/ He participates in competitions $23 \quad 46 \quad 27 \quad 54 \%$ of the classroom arrangements.

The table No. 1 shows that most of the hearing impaired children are good enough ( $96 \%$ ) as they greet their teacher, pay attention to the teacher during lesson( 82 $\%)$, become worried when teacher said that their answer was wrong (94\%), makes different voices during lesson( $88 \%)$, maintain discipline in the classroom(84 \%), respect their elders(72\%), remain calm and quite during lesson(88\%), cooperate with others during group activities (96\%), like to be neat and tidy (92\%), happy to play a game with others $(78 \%)$, play independently(96\%), stay away from fighting during group activities(94\%), follow the rules in playing group games(80\%), care for others during play a game(74 \%), enjoy playing with others(72\%), feel relax after playing a game, eat calmly and quietly(96\%), take interest in Language, Oral Work, Science, Written Work, 
Art, discusses their thoughts with the teacher in the classroom (94\%). Less than half (46\%) share their things with other students while half of them participate in group activities and share their eatable with others (52\%). More than half are friendly with their peers (68\%), obey their teacher's instruction (64\%), and care for their studies (58 $\%)$.

Table 2

Negative Social Behavior $\quad \mathrm{N}=50$

\begin{tabular}{|c|c|c|c|c|c|}
\hline $\begin{array}{l}\text { Item } \\
\text { No. }\end{array}$ & Behavior & Yes & $\begin{array}{l}\% \\
\text { age }\end{array}$ & No & $\%$ age \\
\hline 10 & $\begin{array}{l}\text { She/ He always asks for help during class work } \\
\text { from other students. }\end{array}$ & 10 & 20 & 40 & 80 \\
\hline 11 & She/ He argues with others. & 35 & 70 & 15 & 30 \\
\hline 13 & $\begin{array}{l}\text { She/ He becomes bored (fed up) from } \\
\text { classroom activities. }\end{array}$ & 12 & 24 & 38 & 76 \\
\hline 14 & $\begin{array}{l}\text { She/ He immediately becomes frustrated when } \\
\text { she/ he can't solve a problem. }\end{array}$ & 42 & 84 & 8 & 16 \\
\hline 15 & $\begin{array}{l}\text { She/ He avoids communicating with hearing } \\
\text { children or remain isolated in the class. }\end{array}$ & 6 & 12 & 44 & 88 \\
\hline 16 & $\begin{array}{l}\text { She/ He gest angry when other students } \\
\text { distract her/ him from her/ his studies. }\end{array}$ & 43 & 86 & 7 & 14 \\
\hline 17 & She/ He teases her/ his friends. & 30 & 60 & 20 & 40 \\
\hline 18 & She/ He acts like a rebel during lesson. & 21 & 42 & 29 & 58 \\
\hline 20 & She/ He begins fight with her/ his peers. & 16 & 32 & 34 & 68 \\
\hline 22 & $\begin{array}{l}\text { She/ He becomes aggressive (violent) when } \\
\text { something goes against her/ his will. }\end{array}$ & 36 & 72 & 14 & 28 \\
\hline 24 & She/ He plays all alone (in isolation). & 12 & 24 & 38 & 76 \\
\hline 29 & $\begin{array}{l}\text { She/ He quickly gest annoyed by her/ his peers } \\
\text { while playing. }\end{array}$ & 19 & 38 & 31 & 62 \\
\hline 36 & She/ He snatches others things. & 26 & 52 & 24 & 48 \\
\hline 38 & $\begin{array}{l}\text { She/He does not take interest in Mathematics, } \\
\text { Islamic studies, and Social studies }\end{array}$ & 21 & 42 & 29 & 58 \\
\hline
\end{tabular}

Table 2 shows that most of the hearing impaired children ( $80 \%$ ) did not ask for help during class work, $70 \%$ argue with others, $76 \%$ did not become bored (fed up) from classroom activities, $88 \%$ did not avoids communicating with hearing children, 76 $\%$ did not play alone (in isolation). More than half $62 \%$ did not get annoyed quickly by their peers, $(60 \%)$ teased their friends, $58 \%$ of them did not act a rebel during lesson, $68 \%$ did not begin fight with their peers, $(52 \%)$ children snatch others things. on the other hand $84 \%$ immediately become frustrated when they can't solve a problem, $86 \%$ of the hearing impaired children get angry when other students distract them from their studies, $72 \%$ become aggressive (violent) when something goes against their will. While less than half $42 \%$ did not take interest in mathematics, Islamiat, and social studies 
Table 3

Gender wise positive Social Behavior $\quad \mathbf{n}=25$

\begin{tabular}{|c|c|c|c|c|c|c|c|c|c|}
\hline \multirow[t]{2}{*}{$\begin{array}{l}\text { Item } \\
\text { No. }\end{array}$} & \multirow[t]{2}{*}{ Behavior } & \multicolumn{4}{|c|}{$\begin{array}{l}\text { Male Children with } \\
\text { hearing impairment }\end{array}$} & \multicolumn{4}{|c|}{$\begin{array}{l}\text { Female Children with } \\
\text { hearing impairment }\end{array}$} \\
\hline & & Yes & $\begin{array}{l}\% \\
\text { age }\end{array}$ & No & $\begin{array}{l}\% \\
\text { age }\end{array}$ & Yes & $\begin{array}{l}\% \\
\text { age }\end{array}$ & No & $\begin{array}{l}\% \\
\text { age }\end{array}$ \\
\hline 1 & $\begin{array}{l}\text { He/she greets teacher without } \\
\text { reminder. }\end{array}$ & 15 & 60 & 10 & 40 & 22 & 88 & 03 & 12 \\
\hline 2 & $\begin{array}{l}\mathrm{He} / \text { she pays attention to the } \\
\text { teacher during lesson. }\end{array}$ & 12 & 48 & 13 & 52 & 15 & 60 & 10 & 40 \\
\hline 3 & $\begin{array}{l}\text { He/she becomes worried when } \\
\text { teacher says her/ his answer is } \\
\text { wrong. }\end{array}$ & 20 & 80 & 05 & 20 & 12 & 48 & 13 & 52 \\
\hline 4 & $\begin{array}{l}\text { He/she makes different voices } \\
\text { during lesson and makes noise. }\end{array}$ & 15 & 60 & 10 & 40 & 14 & 56 & 11 & 44 \\
\hline 5 & $\begin{array}{l}\mathrm{He} / \text { she maintains discipline in the } \\
\text { classroom. }\end{array}$ & 18 & 72 & 07 & 28 & 20 & 80 & 05 & 20 \\
\hline 6 & $\begin{array}{l}\mathrm{He} / \text { she gives respect to her/ his } \\
\text { elders. }\end{array}$ & 20 & 80 & 05 & 20 & 15 & 60 & 10 & 40 \\
\hline 7 & He/she cares for her/ his studies. & 15 & 60 & 10 & 40 & 18 & 72 & 07 & 28 \\
\hline 8 & $\begin{array}{l}\mathrm{He} / \text { she obeys teacher's } \\
\text { instructions. }\end{array}$ & 10 & 40 & 15 & 60 & 19 & 76 & 06 & 24 \\
\hline 9 & $\begin{array}{l}\text { He/she remains calm and quite } \\
\text { during lesson. }\end{array}$ & 18 & 72 & 07 & 28 & 22 & 88 & 03 & 12 \\
\hline 12 & $\mathrm{He} /$ she is friendly with his peers. & 22 & 88 & 3 & 12 & 23 & 92 & 02 & 8 \\
\hline 19 & $\begin{array}{l}\text { He/she shares her / his things } \\
\text { with others. }\end{array}$ & 12 & 48 & 13 & 52 & 16 & 64 & 09 & 36 \\
\hline 21 & $\begin{array}{l}\mathrm{He} / \text { she participates in group } \\
\text { activities. }\end{array}$ & 12 & 48 & 13 & 52 & 18 & 72 & 07 & 28 \\
\hline 23 & $\begin{array}{l}\mathrm{He} / \text { she cooperates with others } \\
\text { during group activities. }\end{array}$ & 19 & 76 & 06 & 24 & 23 & 92 & 02 & 8 \\
\hline 25 & $\mathrm{He} /$ she likes to be neat and tidy. & 16 & 64 & 09 & 36 & 20 & 80 & 05 & 20 \\
\hline 26 & $\begin{array}{l}\mathrm{He} / \text { she is happy to play a game } \\
\text { with others. }\end{array}$ & 18 & 72 & 07 & 28 & 16 & 64 & 09 & 36 \\
\hline 27 & He/she plays independently. & 20 & 80 & 05 & 20 & 22 & 88 & 03 & 12 \\
\hline 28 & $\begin{array}{l}\text { He/she stays away from fighting } \\
\text { during group activity }\end{array}$ & 19 & 76 & 06 & 24 & 19 & 76 & 06 & 24 \\
\hline 30 & $\begin{array}{l}\mathrm{He} / \mathrm{she} \text { follows the rules in } \\
\text { playing group games. }\end{array}$ & 15 & 60 & 10 & 40 & 23 & 92 & 02 & 8 \\
\hline 31 & $\begin{array}{l}\text { He/she cares for others during } \\
\text { play a game. }\end{array}$ & 17 & 68 & 08 & 32 & 23 & 92 & 02 & 8 \\
\hline 32 & $\begin{array}{l}\text { He/she enjoys playing with } \\
\text { others. }\end{array}$ & 22 & 88 & 03 & 12 & 22 & 88 & 03 & 12 \\
\hline 33 & $\begin{array}{l}\text { He/she feels relax after playing a } \\
\text { game. }\end{array}$ & 10 & 40 & 15 & 60 & 16 & 64 & 09 & 36 \\
\hline 34 & He/she eats calmly and quietly. & 14 & 56 & 11 & 44 & 21 & 84 & 04 & 16 \\
\hline 35 & $\begin{array}{l}\text { He/she shares her/ his eatable } \\
\text { with others. }\end{array}$ & 16 & 64 & 09 & 36 & 17 & 68 & 08 & 32 \\
\hline
\end{tabular}




\begin{tabular}{|c|c|c|c|c|c|c|c|c|}
\hline 37 & $\begin{array}{l}\text { He/she takes interest in } 16 \\
\text { Language, Oral work, Science, } \\
\text { Written work, and Art }\end{array}$ & 64 & 09 & 36 & 10 & 40 & 15 & 60 \\
\hline 39 & $\begin{array}{l}\text { He/she discusses her/ his } 08 \\
\text { thoughts with the teacher in the } \\
\text { classroom. }\end{array}$ & 32 & 17 & 68 & 09 & 36 & 16 & 64 \\
\hline 40 & $\begin{array}{l}\mathrm{He} / \text { she participates in } 12 \\
\text { competitions of the classroom } \\
\text { arrangements. }\end{array}$ & 48 & 13 & 52 & 19 & 76 & 06 & 24 \\
\hline
\end{tabular}

Table No.3 shows that male hearing impaired children are good enough as $60 \%$ greet their teacher, $80 \%$ become worried when teacher said that their answer was wrong, 60 $\%$ produced different voices during lesson and make noise, $72 \%$ of the male hearing impaired children maintain discipline in the classroom, $80 \%$ respect their elders, $60 \%$ care for their studies, $72 \%$ remain calm and quite during lesson, $88 \%$ friendly with their peers, $76 \%$ cooperate with others during group activities, $64 \%$ like to be neat and tidy, $72 \%$ happy to play a game with others, $80 \%$ play independently, $76 \%$ stay away from fighting during group activities, $60 \%$ follow the rules in playing group games, $68 \%$ care for others during play a game, $88 \%$ enjoy playing with others, $56 \%$ eat calmly and quietly, $64 \%$ share their eatable with others, $64 \%$ take interest in language, oral work, science, written work, art. Few $32 \%$ discussed their thoughts with the teacher in the classroom. Less than half male children with hearing impairment (40\%) obey their teacher's instruction, feel relax after playing a game, (48\%) share their things with other students, participate in group activities, pay attention to the teacher during lesson, participate in competitions of classroom decoration while more than half did not participate in competitions.

Table No.3 also shows that female hearing impaired children are also good enough as 88 $\%$ greet their teacher, $60 \%$ pay attention to the teacher during lesson, $80 \%$ of the male hearing impaired children maintain discipline in the classroom, $72 \%$ care for their studies, $76 \%$ obey their teacher's instruction, $88 \%$ remain calm and quite during lesson, $92 \%$ friendly with their peers, $72 \%$ participate in group activities, $92 \%$ cooperate with others during group activities, $80 \%$ like to be neat and tidy, $88 \%$ play independently, 76 $\%$ stay away from fighting during group activities, $92 \%$ follow the rules in playing group games, $92 \%$ care for others during play a game, $88 \%$ enjoy playing with others, $64 \%$ feel relax after playing a game, $84 \%$ eat calmly and quietly, and $76 \%$ participate in competitions of classroom decoration. Few of the female $36 \%$ share their thoughts with others and $40 \%$ take interest in language, oral work, science, written work, art. Less than half ( $48 \%$ ) become worried when teacher said that their answer was wrong while more than half ( $56 \%$ ) produced different voices during lesson and make noise, $60 \%$ respect their elders, $64 \%$ share their things with other students, $64 \%$ happy to play a game with others, and $68 \%$ share their eatable with others.

Table 4

Gender wise negative Social Behavior $\quad \mathrm{n}=\mathbf{2 5}$

\begin{tabular}{|lllll|}
\hline Item & Behavior & $\begin{array}{l}\text { Male } \\
\text { impaired Children }\end{array}$ & $\begin{array}{l}\text { hearing } \\
\text { No. }\end{array}$ & impaired Children
\end{tabular}




\begin{tabular}{|c|c|c|c|c|c|c|c|c|c|}
\hline & & \multirow[t]{2}{*}{ Yes } & $\%$ & No & $\%$ & Yes & $\%$ & No & \multirow{2}{*}{$\begin{array}{l}\% \\
\text { age }\end{array}$} \\
\hline & & & age & & age & & age & & \\
\hline 10 & $\begin{array}{l}\text { He always asks for help during } \\
\text { class work from other students. }\end{array}$ & 16 & 64 & 09 & 36 & 08 & 32 & 17 & 68 \\
\hline 11 & He argues with others. & 15 & 60 & 10 & 40 & 10 & 40 & 15 & 60 \\
\hline 13 & $\begin{array}{l}\text { He becomes bored (fed up) from } \\
\text { classroom activities. }\end{array}$ & 13 & 52 & 12 & 48 & 12 & 48 & 13 & 52 \\
\hline 14 & $\begin{array}{l}\text { He immediately becomes } \\
\text { frustrated when she/ he can't } \\
\text { solve a problem. }\end{array}$ & 15 & 60 & 10 & 40 & 14 & 56 & 11 & 44 \\
\hline 15 & $\begin{array}{l}\text { He avoids communicating with } \\
\text { hearing children or remains } \\
\text { isolated in the class. }\end{array}$ & 12 & 48 & 13 & 52 & 10 & 40 & 15 & 60 \\
\hline 16 & $\begin{array}{l}\text { He gets angry when other } \\
\text { students distract her/ him from } \\
\text { his studies. }\end{array}$ & 14 & 56 & 11 & 44 & 13 & 52 & 12 & 48 \\
\hline 17 & He teases his friends. & 10 & 40 & 15 & 60 & 12 & 48 & 13 & 52 \\
\hline 18 & He acts like a rebel during lesson. & 05 & 20 & 20 & 80 & 10 & 40 & 15 & 60 \\
\hline 20 & He begins fight with his peers. & 11 & 44 & 14 & 56 & 05 & 20 & 20 & 80 \\
\hline 22 & $\begin{array}{l}\text { He becomes aggressive (violent) } \\
\text { when something goes against } \\
\text { her/ his will. }\end{array}$ & 06 & 24 & 19 & 76 & 15 & 60 & 10 & 40 \\
\hline 24 & He plays all alone (in isolation). & 10 & 40 & 15 & 60 & 11 & 44 & 14 & 56 \\
\hline 29 & $\begin{array}{l}\text { He quickly gets annoyed by his } \\
\text { peers while playing. }\end{array}$ & 09 & 36 & 16 & 64 & 10 & 40 & 15 & 60 \\
\hline 36 & He snatches others things. & 05 & 20 & 20 & 80 & 05 & 20 & 20 & 80 \\
\hline 38 & $\begin{array}{l}\text { He does not take interest in } \\
\text { Mathematics, Islamic studies and } \\
\text { Social studies }\end{array}$ & 12 & 48 & 13 & 52 & 16 & 64 & 09 & 36 \\
\hline
\end{tabular}

Table No. 4 shows that $64 \%$ of the male hearing impaired children always ask for help from others during class work, $60 \%$ argue with others, $60 \%$ immediately become frustrated when they can't solve a problem. More than half $56 \%$ of the male hearing impaired children get angry when other students distract them from their studies, $52 \%$ got bored (fed up) from classroom activities, while less than half $48 \%$ avoids communicating with hearing children and remains isolated in the class, $40 \%$ of the male hearing impaired children teased their friends.

Only few (20\%) of the male hearing impaired children act like a rebel during lesson, $20 \%$ snatch others things, $24 \%$ become aggressive (violent) when something goes against their will. Similarly less than half of the male hearing impaired children 46 $\%$ plays all alone (in isolation), $44 \%$ begins fight with their peers, $36 \%$ quickly gets annoyed by their peers while playing, $48 \%$ take interest in mathematics, Islamic studies, social studies. 
Table No.4 also shows that most of the female hearing impaired children (60\%) become aggressive (violent) when something goes against their will and $64 \%$ take interest in mathematics, Islamic studies, social studies.

More than half of female (52\%) avoids communicating with hearing children and remain isolated in the class, $56 \%$ of female immediately become frustrated when they can't solve a problem. Whereas less than half of the female hearing impaired children (40\%) get angry when other students distract them from their studies, $40 \%$ female act like a rebel during lesson, $40 \%$ female quickly gets annoyed by their peers while playing, $40 \%$ female argue with others, and $44 \%$ female plays all alone (in isolation). $48 \%$ of the female hearing impaired children got bored (fed up) from classroom activities, and the same proportion teased their friends. Only few female (20 $\%)$ snatch others things and begins fighting with their peers, $32 \%$ of the female hearing impaired children always ask for help from others during class work.

\section{DISCUSSION}

Children with hearing impairment show mixed types of social behavior in classrooms. The results of the study are in consistent with the result of Brown, Remine, Prescall and Richards (2000) who found hearing impaired children using a behavior unrelated to ongoing activity and disrupting the ongoing play to attempt to join in peer interaction.

The results revealed of fifty parent children took part in group activities, share their thoughts with teacher and majority immediately became frustrated and do not participate in competitive classroom arrangements, majority play independently. It shows unawareness of hearing impaired children about social interaction as Anita Recd \& Show (2011) reported. Hearing impaired children may be discouraged in taking part as miss understood in initiating conversation as reported by Weirel, Most \& Efron (2005) that hearing impaired children probably start conversation with wrong signals which cannot be understood.

Results also revealed that more than fifty percent hearing impaired children tease their friends and majority got angry when distracted by their peer. The reason may be as Brown, Remine, Prescott \& Richards (2000) found out that hearing impaired children disrupt or tease when they want to join in peer interaction. Results of the study regarding positive behavior; caring for others and anxious for studies and respectful are supported by the literature on positive social behavior. Similarly the results on negative behavior such as hesitate communication behave rudely in certain circumstances support same finding in literature.

\section{CONCLUSIONS}

The study concludes that hearing impaired children show positive social behavior to care for others, when participate in group activities, and discuss their thoughts with the teacher, pay attention to the teacher as they obeyed his 
instructions, follow discipline rules as majority remained calm and quite in classroom, respect elders, cooperates with others company and stay away from fighting, enjoy others company. Whereas some hearing impaired children do not care for their duties, do not follow instructions, do not share their belonging with others, do not discuss their thoughts with teachers, do not participate in competition. While interacting in groups they showed positive behavior such as cooperation, enjoy playing with others, became relax after game, follow rules in game, care for others turn. These results are in consistent with findings of Qayyum \& Nadeem (2012) who conclude play as a strong tool for strengthening their potentials and builds their behaviors and personalities. Majority of hearing impaired children take interest in particular school subjects much as languages, oral work, science, written work and art.

On the other hearing impaired children understand lessons and do not ask for help from others, do not remain isolate but make friends. Some of hearing impaired children become bored during classroom activities, tease their friends, begin fight with peer, play alone and sometimes they act like rebel during lesson, quickly get annoyed by their peers during play, snatch other things and similarly sometimes take interest in Mathematics, Islamic Studies and Social Studies.

Gender wise differences can be concluded from the results that girls more than boys pay attention to the lesson, share their things, participate in groups, cooperate with members, be neat and clean, follow rules, care for others, eat, quietly, and participate in class arrangements. Boys as compared to girls feel happier to play game. Similarly majority boys become worried on wrong answers of the questions, take interest in school subjects, languages, oral work, science and art, while majority of girls do not. Majority of girls remain quite during lessons, become relax after play while majority of boys do not. On positive social behavior such as independent play, calm play and group activities, enjoyment in play and game, maintaining discipline and on sharing no gender differences were found.

Results of the study regarding negative social behavior of hearing impaired children revealed that boys always do not consternate on lesson and always ask for help in completing class assignment, argue while discussing, tease others and act like rebel while girls do not. Similarly boys as compared to girls become fed up quickly from class room activities. On the other hand girls as compared to boys hesitate to communicate with hearing people, do not begin fighting, become aggressive, and do not take interest in school subjects. The results revealed no gender difference on negative social behavior like frustration, get angry, quickly frustrated, show anger on distraction, like to play alone because get annoyed by peers during play, snatching of other things.

Hearing impaired children with mild to moderate hearing loss showed positive behavior more than the children with severe nature of hearing impairment. 


\section{RECOMMENDATIONS}

The study recommended that

1. The positive classroom social behavior of hearing impaired children such as, greeting their teachers, respecting the elders, caring for others, sharing the things, avoiding communicating with hearing children's, staying away from fighting, participating in group activities, being happy to play a game with others, playing independently, following the rules, eating calmly and quietly, participating in competitions should be improved.

2. The negative classroom social behavior of hearing impaired children such as; asking for help in class work, becoming frustrated when can't solve the problem, getting angry when other students distract him/ her from studies, acting like a rebel, begin fighting with the peers, playing alone, quickly getting annoyed by the peers while playing, snatching other's things and not taking interest in their academic subjects should be restricted in the classroom by the teacher.

3. The social skills should be the part of lessons given to the hearing impaired children in the classroom.

4. Teachers and the school administrative staff should arrange some activities which enhance positive social behavior of the students and avoid negative behavior.

5. Since there is a great diversity in ages of children with hearing impairment at primary level in schools, therefore the differences in classroom social behavior relating to different age group; 5-7 and 7-10 could not be studied separately in this study but further researches may explore this aspect.

\section{REFERENCES}

Antia, Shirin D. Reed, Susanne and Shaw, Linda (2011). Risk and resilience for social competence: Deaf students in general education classrooms. Resilience in Deaf Children: $\quad$ Adaptation Through Emerginh Adulthood. 2011:139 - 167.

Bat-Chava, Y., Deignan, E. (2001). Peer relationship of children with cochlear implant. Journal of Deaf Studies and Deaf Education, $\quad$ 2001; 6: 186-199.

Brown, P. M., Remine, M.D., Prescott, S.J., \& Rickards, F.W. (2000). Social interactions of preschoolers with and without impaired hearing in integrated kindergarten. Journal of Early Intervention, 23(3), 200-211. URL http://dx.doi.org/10.1177/10538151000230030901.

Galloway and Goodwin (1987). Social interaction. retrieved from encyclopedia.com on (September 25, 2009). 
Henggeler, S. W. and Borduin, C. M. (1990). Family Therapy and Beyond: multisystemic approach to treating the behavior problems of children and adolescents. Pacific Grove, CA: Brooks/Cole.

Marschark, Marc (1997). Psychological Development of Deaf Children. Oxfor University Press. Amazon.com.

Odom, S., McConnell, S., \& McEvoy, M. (1992). Social competence of young children with disabilities. Maryland: Paul H. Brooks Publishing.

Qayyum, H. A., \& Nadeem, S. (2012). "Exploring Play Pattern and Behaviors of Children with Hearing \& Speech Impairments at Special Schools in Karachi, Pakistan". Human Development Programme The Aga Khan University, $6^{\text {th }}$ Nov, Jakarta, Indonesia 2012. Retrieved from www.arnec.net/ntuc/slot/u2323/.../ppt/ARNEC-2013\%20Sanober.pptx.

Todd, D., \& McLaughlin, M. (2002). Social skills groups for special needs students. Retrieved on November 28, 2003 from www.ispaweb.org

Vandell, D.L. \& George, L.B. (1981). Social interaction in hearing and deaf preschoolers: Successes and failures in initiations. Child Development, 52, 627635.

Vernon, M., \& Andrews, J. (1990). The Psychology of Deafness. New York, NY: Longman.

Weisel, A., Most, T., Efron, C. (2005). Imitation of social interactions by young hearing impaired preschoolers. Journal of Deaf Studies and Deaf Education, 2005; 10: 161-170. 